\title{
The Value Relevance of IFRS Adoption in Indonesia
}

\author{
Juniarti $^{*}$, Ferbiana Helena ${ }^{1}$, Karina Novitasari ${ }^{1}$, and Wenny Tjamdinata ${ }^{1}$ \\ ${ }^{1}$ Program Studi Akuntansi, Fakultas Ekonomi, Universitas Kristen Petra \\ Jl. Siwalankerto 121-131, Surabaya 60236, INDONESIA \\ *Corresponding author; Email: yunie@petra.ac.id
}

\begin{abstract}
Pros and cons of the benefits of IFRS adoption have become an ongoing debate following the inconclusive results of prior studies. Whether IFRS increase value relevance of accounting information or not, especially in developing countries is an interesting and relevance research question. Indonesia as one of the developing countries that committed to adopting IFRS has an interest in obtaining empiric evidence on the value relevance of accounting information after nearly five years of IFRS implementation. This study aims to fill the need to enhance adopters' compliance with the standard. Ohlson Modified Model (1995) is used to test the value relevance of accounting information. Using longitudinal data of listed manufacturing companies in Indonesia Stock Exchange (IDX), this study confirms that value relevance of accounting information increase after IFRS adoption than before adoption. The results robust using Pooled Least Square and Random effect model.
\end{abstract}

Keywords: IFRS adoption; value relevance; accounting information; stock prices.

\section{INTRODUCTION}

Unlike the US GAAP which rely on rulebased and historical cost, IFRS as a new standard focus on principle based and fair value. The proponents of IFRS argue that this standard provides more value relevance than the old one [2]. Accounting information has a value relevance when this information can influence investors to revise their prior decision on firm value [29].

IFRS is aimed to increase the information content of financial reporting, to reduce reporting lag and to enhance the foreign investment inflows [35]. Further, the adoption of IFRS is also expected to enrich transparency and value relevance of financial information [39;47]. Besides its proposed benefits, the adoption of IFRS is costly. The costs include the cost of implementation, training costs, IT investigation, audit fee, renegotiation of debt and others [14]. The costs of IFRS adoption are expected to be less than the benefits.

A number of studies on IFRS adoption have been conducted in developed countries [9; 28; 36; $43 ; 27 ; 56 ; 38 ; 50 ; 5 ; 45 ; 13 ; 17 ; 4 ; 18 ; 47 ; 1 ; 41 ; 10]$, with positive result. $[16 ; 6]$ find negative result. However, the results did not entirely support the notion that IFRS adoption increases value relevance.

Current studies in developing countries also show conflicting results. Some studies suggest that IFRS adoption increase value relevance [7; 29; 24; $8 ; 31 ; 39 ; 59 ; 46]$. While other studies uncovered the opposite finding. They found negative associa- tion between IFRS adoption and value relevance [30; 58]. The varying results have to lead to sharp debates among researchers whether IFRS adoption augments value relevance or not.

As one of the developing countries and the member of the G20, Indonesia has committed to convergence to IFRS starting in 2012 [23]. The significant changes of accounting standard can alarm for some parties, including managers and investors since the cost of adoption is very high. It is essential to adopters in Indonesia to grasp the benefit of the passage. Unfortunately, research on the value relevance of IFRS adoption in Indonesia is very rare. A survey that related to IFRS adoption in Indonesia [33] only focus on the association between IFRS and earning quality and does not specifically investigate the value relevance of the passage. The benefit of IFRS adoption is important to be examined to promote the compliance of the standard since there is no direct incentive promised to the adopters.

Moreover, in Indonesia, it is the right time to begin examining the benefit of IFRS adoption after its five years of implementation. Prior research only investigated several years before the passage. Therefore, the results did not pertain to the value relevance of IFRS adoption.

To overcome the inconsistency of prior results, this study will compare several years before and after adoption. The usage of longitudinal data in this study helps to capture the changes over time and among firms. 
This study is also the first in examining value relevance of IFRS adoption in Indonesia using longitudinal data. Unlike prior studies that try to grab all benefits of IFRS adoption in one study, this research focuses only on the value relevance of passage according to the aim of the issuing of IFRS itself. Therefore the results are expected to contribute to study on IFRS adoption in developing countries that so far is very rare, and its results are still inconclusive.

\section{The Development of Accounting Standards in Indonesia}

Indonesia has a series of financial reporting standard development. It was started from period 1973-1984 when Indonesia Institute of Accountant (the IAI) established the accounting standards that known as Indonesia Accounting Principles (IAPs). In 1984, these rules were revised to be IAPs -1984 . At the end of 1994, The Committee of IAPs started with the numerous revision of accounting standards and resulting 35 pronouncements which majority of them in line with International Accounting Standards published by International Accounting Standard Board (IASB). Since 1994 until 2004, there was a significant change in platform, where Indonesia Accounting Standard Setter moved from US GAAP platform to International Standards platform [51]. There is a substantial difference between both standards, the first one focus on rule-based and historical cost, while the rest uses principle-based and fair value.

Early in 2004, the convergence of IFRS has become a commitment for Indonesia. The Financial Accounting Standard Setter (DSAK) under IAI has played a significant role in promoting IFRS convergence among G20 members especially in South East Asia [23].

The stages of IFRS convergence begin with the adoption stage of 2008-2010, the preparation stage in 2011 and the implementation stage in 2012. However, many firms have initiated to voluntary adopted earlier. Therefore in this study, we used 2011 as the cut off year for post-adoption.

\section{Value Relevance}

To accommodate the need for relevant information, IFRS has focused on fair value approach. The using of this method is expected to be responded by the market through the changes of stock prices [21]. IFRS adoption will produce competent financial reporting thus increasing its value relevance $[39 ; 2]$.Value relevance refers to the capability of accounting information to portrait the firm value, so that is capable of making investors revise their prior decisions [15]. The changes of investors' choice are represented in the variations of stock prices. The higher the association of accounting information and stock prices, the higher the value relevance of accounting information [3]. Accounting information will be considered to have a value relevance when stock prices fluctuate due to the report [20].

This study bases on Ohlson model (1995) in measuring value relevance of accounting information. This is done by investigating the association of information content of accounting earning, i.e., earning per share, book value per share and stock prices, using the following model:

$P_{i, t}=\alpha_{0}+\alpha_{1} B V_{i t}+\alpha_{2} E P S_{i t}+\alpha_{3}$ CFOS $_{i t}+\varepsilon_{i t}$

Where:

$\mathrm{BV}=$ book value of equity firm $\mathrm{i}$, year $\mathrm{t}$

EPS = earning per share firm $\mathrm{i}$, year $\mathrm{t}$

$\mathrm{CFOS}=$ cash from operating per share firm $\mathrm{i}$, year $\mathrm{t}$

The statistical association between accounting information that proxied by EPS, BVPS or CFOS, and stock prices, imply the existence of value relevance [53]. According to [44] accounting earning has value relevance if it was capable of altering stock prices. The variation of stock prices as a representation of investors'response.

\section{IFRS Adoption and Value Relevance}

Value relevance shows the level of association between accounting information and stock prices, the higher the level of relationship means the higher the value relevance of the report $[3 ; 15]$. Accounting information has value relevance if stock prices react over the data [20;37].

Accounting information compiled under IFRS will better describe the current state of firm value and has a higher level of comparison. Thus the transparency and the comparability of financial reporting increase for firms that adopt IFRS. Once the transparency increase, the information asymmetry between internal and external parties such as managers and owners, majority and minority investors will reduce. Investors value the lower estimation risk of companies and thus reduce the cost of capital. On the other hand, the improvement of comparability makes easier for investors to compare performance among businesses and worldwide. Investors'confidence over the accounting information increase. Further, it will influence investors' decisions as reflected by the changes in stock prices. When accounting information affects the investor response, the accounting information has value relevance. 
It is expected that post-adoption IFRS will have more value relevance accounting information than pre-adoption. It also has been supported by some prior researchers, among others are $[8 ; 29$; $24 ; 7 ; 31 ; 39 ; 59]$. They documented that the value relevance of accounting information increase after IFRS adoption, it means that there was a higher association between accounting information and stock prices in post-IFRS adoption. Therefore, this research proposes the following hypothesis:

H1: There was an increase of value relevance of accounting information in post-IFRS adoption.

\section{RESEARCH METHODS}

This study predicts that there is an increasing of the value relevance of accounting information after IFRS adoption. To test the hypothesis, this study assesses the value relevance of accounting information four years before passage (20072010) and four years after adoption (2011-2014) using modified Ohlson Model (1995), then compared $\mathrm{R}^{2}$ of pre and post adoption. If $\mathrm{R}^{2}$ after adoption increase and the model fit, in which probF or prob-Chi2 less than 0,1 or 0,05 , the hypothesis is confirmed. The value relevance is measured by the level of association of accounting information and stock prices. Three proxies represent accounting information are earning per share (EPS), book value equity per share (BVPS), and cash flow from operating per share (CFOS). Stock prices are the average ten days of stock prices after three months of the publication date of financial reporting.

EPS indicates net income available for common shareholders. It obtains from net income fewer dividends on preferred shares scaled by the weighted average of common stock outstanding [13]. BVPS refers to total equity scaled by weighted average outstanding share [5]. While CFOS is cash flow from operating scaled by weighted average common share outstanding.

The sample is selected using the following criteria; (1) firm listed in Indonesia Stock Exchange since 2007, (2) staying at public companies for the period 2007-2014 and (3) has adopted IFRS since 2011. The sample in this research is all manufacturing companies. 60 firms in each sample group qualify the criteria. In total, we have 480 firm-year in both sample groups. The source of accounting and stock prices data are from Bloomberg and YahooFinance.

\section{RESULTS}

Profile of variables of each of sample groups (pre-adoption, post adoption and total) are presented in table 1 and 2 , as follows.
Table 1. Pairwise Correlation

\begin{tabular}{lllll}
\hline \multirow{2}{*}{ EPS } & EPS & BVPS & CFOS & SPRICE \\
& 1,0000 & & & \\
BVPS & $0,9029 * * *$ & 1,0000 & & \\
& 0,0000 & & & \\
CFOS & $0,5364 * * *$ & $0,6087 * * *$ & 1,0000 & \\
& 0,0000 & 0,0000 & & \\
SPRICE & $0,9328 * * *$ & $0,8911 * * *$ & $0,4976 * * *$ & 1,0000 \\
& 0,0000 & 0,0000 & 0,0000 & \\
\hline
\end{tabular}

The table shows a significant correlation between independent variables of EPS and BVPS to the Share price.

Table 2. Mean Difference between Pre and Post Adoption

\begin{tabular}{lrrrr}
\hline & Pre Adoption Post Adoption Total Sample & t-test \\
\hline EPS & 68,853 & 116,548 & 944,599 & $-1,878$ \\
BVPS & 574,423 & 954,031 & 764,227 & $-2,495$ \\
CFOS & 79,384 & 86,903 & 83,143 & $-0,312$ \\
SPRICE & 954,265 & $2.110,971$ & $1.532,618$ & $-2,345$ \\
Obs & 240 & 240 & 480 & \\
\hline
\end{tabular}

\section{Selection of the Best Model}

To determine the best model of panel data of each of sample groups, Chow tests, and Hausman test is applied. From the Chow test of pre-adoption data known that fixed effect is more appropriate since $\mathrm{p}$-value is less than 0,1 , therefore $\mathrm{H}_{0}$ that stated the best model is Pooled Least Square (PLS) is rejected and the fixed effect is the more suitable model. Subsequently, Hausman test is applied to decide whether the fixed effect or random effect is the best model for pre-adoption panel data. The result shows that $\mathrm{H}_{0}$ stated that model is fixed effect model cannot be rejected. Therefore fixed effect is verified as the best model for pre-adoption panel data. Summary of the test of data panel is presented in table 3 .

Table 3 indicates that EPS and BVPS consistently prove as the significant influence on stock price, while CFOS as an additional variable in modified Ohlson model (1995) does not show the same results. Overall, $\mathrm{R}^{2}$ of all model either PLS, fixed effect or random effect model is very high. It supports that the value relevance exists in accounting information.

The results of post-adoption panel data arrive the same conclusion with the pre-adoption test in which fixed effect model proved as the best model. The results are robust either tested with PLS and random effect model, although they are not selected as the best model. Both model still have high $R^{2}$. It indicates that value relevance exists in accounting information. 
Table 3. Summary of PLS, Fixed Effect, and Random Effect Tests-Pre Adoption

\begin{tabular}{|c|c|c|c|c|c|c|}
\hline & \multicolumn{2}{|c|}{ PLS } & \multicolumn{2}{|c|}{ Fixed effect } & \multicolumn{2}{|c|}{ Random effect } \\
\hline & Coef & $\mathrm{t}$ & Coef & $\mathrm{t}$ & Coef & $\mathrm{z}$ \\
\hline$\overline{\text { EPS }}$ & 12.081 & $12.570 * * *$ & 1.486 & 1.480 & 11.256 & $11.330 * * *$ \\
\hline BVPS & 0.674 & $3.530 *$ & 8.496 & $15.730 * * *$ & 0.910 & $4.150 * * *$ \\
\hline CFOS & 0.520 & 0.860 & -0.142 & -0.300 & 0.712 & 1.190 \\
\hline Const. & -305.930 & $-2.610 * *$ & 4016.909 & $-15.380 * * *$ & -440.213 & $-2.430 * *$ \\
\hline Adj R-sq & & & & & & \\
\hline between & & & 0.812 & & & 0.605 \\
\hline within & & & 0.849 & & & 0.926 \\
\hline overall & 0.818 & & 0.709 & & & 0.819 \\
\hline $\mathrm{F}$ & 359.900 & & 254.000 & & & 706.210 \\
\hline Prob-F & 0.000 & & 0.000 & & & 0.000 \\
\hline
\end{tabular}

Table 4. Summary of PLS, Fixed Effect, and Random Effect Tests-Post Adoption

\begin{tabular}{|c|c|c|c|c|c|c|}
\hline & \multicolumn{2}{|c|}{ PLS } & \multicolumn{2}{|c|}{ Fixed effect } & \multicolumn{2}{|c|}{ Random effect } \\
\hline & Coef & $\mathrm{t}$ & Coef & $\mathrm{t}$ & Coef & $\mathrm{z}$ \\
\hline$\overline{\mathrm{EPS}}$ & 14.439 & $14.560 * * *$ & 1.829 & $2.290 * * *$ & 8.630 & $7.960 * * *$ \\
\hline BVPS & 0.955 & $5.590 * * *$ & -1.531 & $-8.750 * * * *$ & 1.039 & $5.080 * * *$ \\
\hline CFOS & -1.559 & $-2.760 * * *$ & -0.793 & $-2.910^{* * * *}$ & -0.952 & $-2.030 * *$ \\
\hline Const. & -347.982 & $-2.410 * *$ & 4016.909 & $-15.380 * * *$ & -196.703 & 0.580 \\
\hline Adj R-sq & & & & & & \\
\hline between & & & 0.359 & & 0.012 & \\
\hline within & & & 0.825 & & 0.950 & \\
\hline overall & 0.910 & & 0.762 & & 0.908 & \\
\hline $\mathrm{F}$ & 810.360 & & 32.970 & & 291.280 & \\
\hline Prob-F & 0.000 & & 0.000 & & 0.000 & \\
\hline
\end{tabular}

Table 5. Hypothesis Testing

\begin{tabular}{lclrl}
\hline & \multicolumn{2}{c}{ Post Adoption } & \multicolumn{2}{c}{ Pre Adoption } \\
& Coef & \multicolumn{1}{c}{$\mathrm{t}$} & \multicolumn{1}{c}{ Coef } & \multicolumn{1}{c}{$\mathrm{t}$} \\
\hline EPS & 0,229 & $4,130 * * *$ & 0,115 & $2,300 * *$ \\
BVPS & 0,186 & 1,060 & 1,544 & $6,170 * * *$ \\
CFOS & 0,056 & $1,320 * *$ & $-0,051$ & $-0,890$ \\
Const. & 4,425 & $4,190 * * *$ & $-3,194$ & $-2,370 * *$ \\
& & & & \\
Adj R-sq & & & & \\
between & 0,186 & & 0,387 & \\
within & 0,711 & & 0,493 & \\
overall & 0,625 & & 0,512 & \\
& & & & \\
F & 8,290 & & 23,400 & \\
Prob-F & 0,000 & & 0,000 & \\
\hline
\end{tabular}

$\mathrm{R}^{2}$ of each of model seems higher than the preadoption data, but the conclusion cannot be drawn from this model since fixed effect model has heteroscedasticity problem that needs to be fixed first.

\section{Heteroscedasticity Test}

The common problem in fixed effect model is heteroscedasticity; therefore this issue should be mitigated. Breusch-Pagan/Cook-Weisberg test for heteroscedasticity applied to detect heteroscedasticity and the results show that prob-chi2 of fixed effect model for both pre and post adoption less than 0,05 . It means that heteroscedasticity exists in both models. To overcome this problem, data is converted into logarithmic. The results of heteroscedasticity tests after data transformation prove that the issues have been mitigated as indicated by the value of prob-chi2 for both models is higher than 0,05 .

After the heteroscedasticity problem mitigated, data is rerun using fixed-effect model. The results of fixed effect model for both pre and post adoption are as follow (Table 5)

\section{DISCUSSION}

IFRS adoption is intended to increase transparency and comparability of accounting information [47; 39]. Higher quality of accounting information will improve the investors' confidence in financial reporting since the reports convey information about the firm value to the investors. This study using longitudinal data exhibits that accounting information has information content, and as predicted, $\mathrm{R}^{2}$ in post-adoption is as 0,625 greater than pre-adoption that only has 0,512 . It means that the value relevance of accounting information increase after IFRS adoption. This finding consistent with some prior research especially in developing countries $[7 ; 29 ; 24 ; 8 ; 31 ; 39 ; 59 ; 46]$. The regulation of the Indonesia Standard Setter that mandate firms adopt IFRS remind the ques- 
tion of its benefits. This results can answer the doubts and motivate firms to comply with the standard since the benefit justifies it.

In developing countries like Indonesia with characterized by low investors protection and weak law enforcement, the mandatory of IFRS adoption acts as a new tool to increase the confidence of investors and other users on financial reporting. From the perspective of adopters, the increase of value relevance of accounting information after adopting new standard could be as an incentive for them, in the condition that there is no direct incentive promised to adopters.

The pros and cons around the benefit of IFRS adoption are expected to be narrowed with this results. This study supports the argumentation of proponent of the new standard that it was resulting in more transparent and comparable accounting information.

Following up the prior study that investigates the impact of IFRS adoption in multi-countries that usually too simplified the differences among countries, this study has been applied only in a single state so that the results can be specified. This study proves that IFRS is capable enough to strengthen the quality of accounting information.

This research is supported by [33] which found a positive association of IFRS adoption on accounting information quality. However, this study is the contrast to [34] that found that IFRS adoption has not been able to improve the value relevance of accounting information.

\section{CONCLUSION, LIMITATION AND FUTURE RESEARCH}

The study is the first research that investigates the benefit of IFRS adoption using longitudinal data by comparing the value relevance of accounting information before and after IFRS adoption. The results successfully prove that the value relevance increase after IFRS adoption. This finding is expected to enhance the standard setter confidence to mandate IFRS to all firms consistently. The efforts to adopt IFRS provide excellent results, increase not only the value relevance of accounting information but also the confidence of standard setter.

This result is limited to manufacturing companies, to be more generalizable, future studies need to involve other sectors and extend the period of adoption to get more consistent results.

\section{REFERENCES}

[1] Ahmed, K., Chalmers, K., \& Khlif, H. (2013). A Meta-analysis Of IFRS Adoption Effects. The International Journal Of Accounting 48, 173217.
[2] Ball, R., Robin, A., \& Wu, S. (2003). Incentives Versus Standards: Properties of Accounting Income in Four East Asian Countries. Journal of Accounting and Economics 36, 235 - 270.

[3] Barth, M., Beaver, W., \& Landsman, W. (2001). The Relevance Of The Value Relevance Literature For Financial Accounting Standard Setting: Another View. Journal of Accounting and Economics 31, 77-104.

[4] Barth, M., Landsman, W., \& Lang, M. (2008). International Accounting Standards And Accounting Quality. Journal of Accounting Research 46(3), 467-498.

[5] Beisland, L., \& Knivsflå, K. (2015). Have IFRS Changed How Stock Prices Are Associated With Earnings And Book Values?: Evidence From Norway. Accounting and Finance 14(1), 41-63.

[6] Black, E., \& Maggina, A. (2016). The Impact of IFRS on Financial Statement Data In Greece. Journal of Accounting in Emerging Economies 6(1), 69-90.

[7] Chamisa, E., Mangena, M., \& Ye, G. (2012). Relative Value Relevance of Accounting Measures Based on Chinese Accounting Standards and International Financial Reporting Standards. Journal of Accounting in Emerging Economies 2(2), 162-187.

[8] Chebaane, S., \& Othman, H. (2014). The Impact of IFRS Adoption on Value Relevance of Earnings And Book Value of Equity: The Case of Emerging Markets in African and Asian Regions. Procedia-Social and Behavioral Sciences 145, 70-80.

[9] Clacher, I., Ricquebourg, A., \& Hodgson, A. (2013). The Value Relevance of Direct Cash Flows under International Financial Reporting Standards. Abacus, 29.

[10] Clarkson, P., Hanna, J., Richardson, G., \& Thompson, R. (2011). The Impact of IFRS Adoption on the Value Relevance of Book Value and Earnings. SSRN Electronic Journal, 1-46.

[11] Daske, H., Hail, L., Leuz, C., \& Verdi, R. (2008). Mandatory IFRS Reporting Around The World: Early Evidence On The Economic Consequences. Journal of Accounting Research 12, 1-74.

[12] Ding, Y., Hope, O.-K., Jeanjean, T., \& Stolowy, H. (2007). Differences Between Domestic Accounting Standard and IAS: Measurement, Determinants, and Implications. Journal of Accounting and Public Policy 26, 1-38.

[13] Elbakry, A., Nwachukwu, J., Abdou, H., \& Elshandidy, T. (2017). Comparative Evidence on the Value Relevance of IFRS Based Accounting Information in Germany and the UK. Journal of International Accounting, Auditing, and Taxation 28, 10-30. 
[14] Fox, A., Hannah, G., Helliar, C., \& Veneziani, M. (2013). The Costs and Benefits of IFRS Implementation in the UK and Italy. Journal of Applied Accounting Research 14(1), 86-101.

[15] Francis, J., \& Schipper, K. (1999). Have Financial Statements Lost Their Relevance? Journal of Accounting Research 37(2), 319352.

[16] Garanina, T., \& Kormiltseva, P. (2014). The Effect Of International Financial Reporting Standards (IFRS) Adoption On The Value Relevance Of Financial Reporting: A Case Of Russia. Accounting in Central and Eastern Europe, 27-60.

[17] Garzia, M., Alejandro, K., Saenz, A., \& Sanchez, H. (2017). Does An IFRS Adoption Increase Value Relevance and Earnings Timeliness In Latin America? Emerging Markets Review 30, 155-168.

[18] Gjerde, Ø., Knivsflå, K., \& Sættem, F. (2008). The Value-Relevance of Adopting IFRS: Evidence from 145 NGAAP Restatements. Norges Handelshoyskole 21, 1-53.

[19] Ghozali, I. (2009). Ekonometrika, Teori, Konsep, dan Aplikasi Dengan SPSS 17. Semarang: Universitas Diponegoro.

[20] Holthausen, R., \& Watts, R. (2001). The Relevance Of The Value-Relevance Literature For financial Accounting Standard Setting. Journal of Accounting and Economics 31, 3-75.

[21] Horton, J., Serafeim, G., \& Serafeim, I. (2010). Does Mandatory IFRS Adoption Improve The Information Environment?. Contemporary Accounting Research 4, 1-58.

[22] IFRS. (2017). Who uses IFRS Standards? Retrieved from IFRS: http://www.ifrs.org/usearound-the-world/use-of-ifrs-standards-byjurisdiction/

[23] Ikatan Akuntansi Indonesia. (2017). Pengertian Standar Akuntansi Keuangan (SAK). Retrieved from Ikatan Akuntansi Indonesia: http://iaiglobal.or.id/v03/standar-akuntansikeuangan/sak

[24] Ismail, W., Kamarudin, K., Zijl, T., \& Dunstan, K. (2013). Earnings Quality And The Adoption of IFRS Based Accounting Standards: Evidence from an Emerging Market. Asian Review of Accounting 21(1), 53-73.

[25] Jackson, B., \& Briley, J. (2015). The Responsiveness of Share Price to Operating Cash Flow in Modern Corporate Bankruptcies. Overlaps of Private Sector with Public Sector around the Globe, 135-140.

[26] Janjani, R. (2015). Comparing US-GAAP And Iran-GAAP Operating Cash Flows To Predict Future Cash Flows. Journal of Financial Reporting and Accounting 13(1), 39-65.
[27] Ji, X., \& Lu, W. (2014). The Value Relevance and Reliability of Intangible Assets Evidence from Australia Before and After Adopting IFRS. Emerald Insight, 36.

[28] Kajüter, P., \& Nienhaus, M. (2017). The Impact of IFRS 8 Adoption on the Usefulness Of Segment Reports. ABACUS 53(1), 28-58.

[29] Karğın, S. (2013). The Impact Of IFRS On The Value Relevance of Accounting Information: Evidence From Turkish Firms. International Journal of Economics and Finance 5(4), 71-80.

[30] Khanagha, J. (2011). Value Relevance Of Accounting Information in the United Arab Emirates. International Journal of Economics and Financial Issues 1(2), 33-45.

[31] King'wara, R. (2015). Effect of IFRS Adoption On Reporting Quality in Kenya. IOSR Journal of Business and Management 17(1), 82-84.

[32] Kouser, D., \& Azeem, M. (2011). Relationship Of Share Price With Earnings and Book Value of Equity: Paramount Impact of IFRS Adoption in Pakistan. Economics and Finance Review 1(8), $84-92$.

[33] Krismiaji, Aryani, Y., \& Suhardjanto, D. (2016). International Financial Reporting Standards, Board Governance, and Accounting Quality: A Preliminary Indonesian Evidence. Asian Review of Accounting 24(4), 474497.

[34] Kusumo, Y., \& Subekti, I. (2013). Relevansi Nilai Informasi Akuntansi, Sebelum Adopsi IFRS dan Setelah Adopsi IFRS pada Perusahaan yang Tercatat dalam Bursa Efek Indonesia. Journal of Accounting 17, 1-17.

[35] Landsman, W., Maydew, E., \& Thornock , J. (2011). The Information Content of Annual Earnings Announcements and Mandatory Adoption of IFRS. SSRN Electronic Journal, 1-59.

[36] Ledoux, M.J., \& Cormier, D. (2013). Market Assessment of Intangibles and Voluntary Disclosure About Innovation: The Incidence Of IFRS. Review of Accounting and Finance 12(3), 286-304

[37] Lev, B., \& Zarowin, P. (1999). The Boundaries of Financial Reporting and How to Extend them. Journal of Accounting Research 37(2), 353-385.

[38] Manganaris, P., Spathis, C., \& Dasilas, A. (2016). How Institutional Factors and IFRS Affect the Value Relevance of Conservative and Non-Conservative Banks. Journal of Applied Accounting Research 17(2), 211-236.

[39] Mironiuc, M., Carp, M., \& Chersan, I.-C. (2015). The Relevance of Financial Reporting on the Performance of Quoted Romanian Companies in the Context of Adopting the IFRS. Procedia Economics and Finance 20, 404- 413 . 
[40] Mohammed, Y., \& Lode, N. (2015). The Value Relevance Of Accounting Disclosures Among Nigerian Financial Institutions After The IFRS Adoption. Mediterranean Journal of Social Sciences 6(1), 409-418.

[41] Müller, V.-O. (2014). The Impact of IFRS Adoption on the Quality of Consolidated Financial Reporting. Procedia - Social and Behavioral Sciences 109, 976 - 982.

[42] Murtini, H., \& Lusiana. (2016). Earning Management and Value Relevance Before and After the Adoption of IFRS in Manufacturing Company in Indonesia. Review of Integrative Business and Economics Research 5(1), 241250.

[43] Negakis, C. (2013). The Explanatory Power of Earnings for Stock Returns in the Pre- and Post-IFRS Era Some Evidence from Greece. Emerald Insight, 13.

[44] Ohlson, J. (1995). Earnings, Book Values, And Dividends In Equity Valuation. Contemporary Accounting Research 11(2), 661-687.

[45] Okafor, O., Anderson, M., \& Warsame, H. (2016). IFRS and Value Relevance: EvidenceBased on Canadian Adoption. International Journal of Managerial Finance 12(2), 136-160.

[46] Outa, E., Ozili, P., \& Eisenberg, P. (2017). IFRS Convergence and Revisions: Value Relevance of Accounting Information from East Africa. Emerald Insight, 18.

[47] Păúcan, I.-D. (2015). Measuring The Effects Of IFRS Adoption on Accounting Quality: A Review. Procedia Economics and Finance 32, $580-587$.

[48] Pranata, D., \& Pujiati, D. (2015). The Effect of Liquidity, Profitability, Sales Growth, And Dividend Policy on Stock Prices After The Implementation of IFRS. The Indonesian Accounting Review 5(2), 169 - 178.

[49] Ricquebourg, A., Clacher, I., \& Hodgson , A. (2013). The Value Relevance of Direct Cash Flows Under IFRS. SSRN Electronic Journal, 1-43.

[50] Sahut, J.M., Boulerne, S., \& Teulon, F. (2011). Do IFRS Provide Better Information About
Intangibles in Europe? Review of Accounting and Finance 10(3), 267-290.

[51] Saputra, B. (2012). Perkembangan International Financial Reporting Standard (IFRS) dan Penerapannya di Indonesia. SSRN Electronic Journal, 1-9.

[52] Stock, J., \& Watson, M. (2007). Why Has U.S. Inflation Become Harder To Forecast? Journal of Money, Credit and Banking, Supplement 39(1), 1-31.

[53] Suadiye, G. (2012). Value Relevance of Book Value \& Earnings Under the Local GAAP and IFRS: Evidence from Turkey. Ege Academic Review 12, 301-310.

[54] Sudrajat, W. (1988). Mengenal Ekonometrika Pemula. Bandung: CV. Armco

[55] Tjiasmanto, V., \& Juniarti. (2015). Pengaruh Pengungkapan Corporate Social Responsibility Terhadap Respon Investor dalam Sektor Aneka Industri. Business Accounting Review $3(1), 67-77$.

[56] Tsalavoutas, I., \& Dionysiou, D. (2014). Value Relevance of IFRS Mandatory Disclosure Requirements. Journal of Applied Accounting Research 15(1), 22-42.

[57] Tumbol, W., Poputra, A., \& Runtu, T. (2014). Analisis dengan Menggunakan Informasi Akuntansi Diferensial dalam Pengambilan Keputusan Membeli atau Membuat Sendiri Bakso pada Bakso Pasuruan. Jurnal EMBA 2(2), 1440-1447.

[58] Umobong, A., \& Akani , D. (2015). IFRS Adoption And Accounting Quality of Quoted Manufacturing Firms in Nigeria: A CrossSectional Study of Brewery and Cement Manufacturing Firms. International Journal of Business and Management Review 3(6), 6177.

[59] Vardia, D., Kalra, D., \& Soral, P. (2016). An Impact of IFRS on the Value Relevance of Financial Statements: A Study of Selected Indian Listed Company. Indian Journal of Accounting 18(2), 7-17.

[60] Widarjono, Agus. (2006). Ekonometrika untuk Analisis Ekonomi dan Keuangan. Jakarta: UI. 